\title{
Alkylated epidermal creatine kinase as a biomarker for sulfur mustard exposure: comparison to adducts of albumin and DNA in an in vivo rat study
}

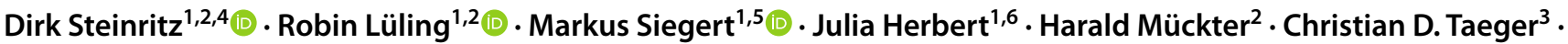 \\ Thomas Gudermann ${ }^{2} \cdot$ Alexander Dietrich $^{2}\left(\mathbb{D} \cdot\right.$ Horst Thiermann $^{1} \cdot$ Harald John ${ }^{1}$ (i)
}

Received: 27 November 2020 / Accepted: 16 February 2021 / Published online: 26 February 2021

(c) The Author(s) 2021

\begin{abstract}
Sulfur mustard (SM) is a chemical warfare agent which use is banned under international law and that has been used recently in Northern Iraq and Syria by the so-called Islamic State. SM induces the alkylation of endogenous proteins like albumin and hemoglobin thus forming covalent adducts that are targeted by bioanalytical methods for the verification of systemic poisoning. We herein report a novel biomarker, namely creatine kinase (CK) B-type, suitable as a local biomarker for SM exposure on the skin. Human and rat skin were proven to contain CK B-type by Western blot analysis. Following exposure to SM ex vivo, the CK-adduct was extracted from homogenates by immunomagnetic separation and proteolyzed afterwards. The cysteine residue $\mathrm{Cys}^{282}$ was found to be alkylated by the SM-specific hydroxyethylthioethyl (HETE)-moiety detected as the biomarker tetrapeptide TC(-HETE)PS. A selective and sensitive micro liquid chromatography-electrospray ionization high-resolution tandem-mass spectrometry ( $\mu \mathrm{LC}$-ESI MS/HRMS) method was developed to monitor local CK-adducts in an in vivo study with rats percutaneously exposed to SM. CK-adduct formation was compared to already established DNA- and systemic albumin biomarkers. CK- and DNA-adducts were successfully detected in biopsies of exposed rat skin as well as albumin-adducts in plasma. Relative biomarker concentrations make the CK-adduct highly appropriate as a local dermal biomarker. In summary, CK or rather $\mathrm{Cys}^{282}$ in CK B-type was identified as a new, additional dermal target of local SM exposures. To our knowledge, it is also the first time that HETE-albumin adducts, and HETE-DNA adducts were monitored simultaneously in an in vivo animal study.
\end{abstract}

Keywords Chemical warfare agents $\cdot$ Micro liquid chromatography $\cdot$ High-resolution tandem-mass spectrometry $\cdot$ Human skin

\begin{tabular}{llll}
\multicolumn{2}{l}{ Abbreviations } & DTT & Dithiothreitol \\
Ade & Adenine & ETE & Ethylthioethyl-moiety \\
b.w. & Body weight & EtOH & Ethanol \\
CE & Collision energy & ESI & Electrospray ionization \\
CES & Collision energy spread & FA & Formic acid \\
CK & Creatine kinase & GS1 & Heater gas \\
CUR & Curtain gas & GS2 & Turbo ion spray gas \\
DNA & Deoxyribonucleic acid & Gua & Guanine \\
DP & Declustering potential & HETE & Hydroxyethylthioethyl-moiety \\
& & HSA & Human serum albumin \\
\hline \multirow{2}{*}{$\begin{array}{l}\text { Dirk Steinritz and Robin Lüling shared first authorship. } \\
\text { Harald Mückter deceased on May 07, 2020. }\end{array}$} & IAA & Iodoacetamide \\
\hline $\begin{array}{l}\text { Dirk Steinritz } \\
\text { dirk.steinritz@lrz.uni-muenchen.de }\end{array}$ & IMS & Immunomagnetic separation \\
Extended author information available on the last page of the article & IRD & Ion release delay \\
\end{tabular}




$\begin{array}{ll}\mu L C & \text { Micro liquid chromatography } \\ \text { MS/HRMS } & \text { High-resolution tandem-mass spectrometry } \\ \text { MS/MS } & \text { Tandem-mass spectrometry } \\ \text { OPCW } & \begin{array}{l}\text { Organisation for the Prohibition of Chemical } \\ \text { Weapons }\end{array} \\ \text { PAGE } & \text { Polyacrylamide gel electrophoresis } \\ \text { PBS } & \text { Phosphate buffered saline } \\ \text { RCF } & \text { Relative centrifugal field } \\ \text { RSA } & \text { Rat serum albumin } \\ \text { RSDL } & \text { Reactive skin decontamination lotion } \\ \text { RT } & \text { Room temperature } \\ \text { SM } & \text { Sulfur mustard, bis-(2-chloroethyl) sulfide } \\ \text { TEM } & \text { Temperature (as ion source setting) } \\ \text { UF } & \text { Ultrafiltration }\end{array}$

\section{Introduction}

Sulfur mustard (SM, bis(2-chloroethyl) sulfide, CAS No. 50560-2) is an internationally banned chemical warfare agent. The Chemical Weapons Convention, that is implemented by the Organisation for the Prohibition of Chemical Weapons (OPCW) (www.opcw.org/chemical-weapons-convention), prohibits its development, production, otherwise acquisition, stockpiling or retaining, transfer, and deployment. Nevertheless, SM has repeatedly been used in Northern Iraq and Syria by the so-called Islamic State (Quillen 2016) as reported by the OPCW in 2015 in Marea (Organisation for the Prohibition of Chemical Weapons 2015) or Kilic et al. who treated patients that were supposed to be exposed to SM in 2016 in Al-Bab (Kilic et al. 2018). Such alleged use of SM represents a serious violation of international law and requires definite evidence. For this purpose, bioanalytical methods are available to verify poisoning by the detection of unambiguous SM-induced covalent modifications of endogenous biomacromolecules, e.g. adducts of DNA and proteins (Gandor et al. 2015; John et al. 2016; Zubel et al. 2018, 2019; Noort et al. 2008). Such protein-adducts were shown to exhibit a half-life of several weeks thereby allowing sampling of plasma and serum even days or weeks after the event (Noort et al. 1996, 1999; Black et al. 1997; Xu et al. 2014; John et al. 2019; Steinritz et al. 2016). Human serum albumin (HSA), alkylated by SM at the only free cysteine residue $\left(\mathrm{Cys}^{34}\right)$ by attaching a hydroxyethylthioethyl-moiety (HETE), is a frequently used protein-adduct to prove exposures (Noort et al. 1999; Gandor et al. 2015). In general, the use of HETE-HSA as biomarker is attractive because it can be assessed in human plasma which is easy to obtain. However, the uptake of SM into the circulation is a prerequisite for the formation of this adduct. Thus, the systemic biomarker generation depends on sufficient SM doses that must be absorbed by inhalation or by penetration of the skin. Especially when delivered as a liquid, the skin is the primary portal of entry for SM. The lipophilicity of SM combined with the affinity of the skin for lipophilic substances promote its uptake into the epidermis. However, only a small fraction of dermally applied SM seems to penetrate. In vitro experiments conducted by Riviere et al. revealed a resorption of only less than 5\% (Riviere et al. 1995). This loss might be caused by e.g. evaporation processes on the warm skin, retention in lipophilic tissue and covalent binding to tissue components like proteins and DNA. Approximately $12 \%$ of a single SM dose reacts with components in the skin, most presumably within the epidermis (Renshaw 1946). Thus, skin exposures with small amounts of liquid SM may not result in systemic biomarker formation due to the limited dermal absorption. Hence, an exposure may not be detected when systemic biomarkers are used for verification in this scenario. This indicates the need for appropriate non-systemic dermal biomarkers.

Methods detecting SM-induced covalent modifications of DNA bases in the epidermis are available (Zubel et al. 2018, 2019). Especially mass spectrometry (MS)-based methods require tissue preparation, partial hydrolysis and isolation of the epidermal DNA. Epidermal skin is estimated to contain only $3 \mathrm{ng}$ DNA per $1 \mu \mathrm{g}$ tissue (Krämer et al. 1971). This low concentration either limits the chance for successful forensic analysis or requires punching of larger skin samples. Approaches addressing alternative, high abundant biomarkers may close this gap. As reported previously by our group, SM targets the reactive cysteine 282 residue $\left(\mathrm{Cys}^{282}\right)$ in human creatine kinase (CK) adding the HETE-moiety (Lüling et al. 2020). Moreover, CK is present in the epidermis (Schlattner et al. 2002). Both aspects suggest the use of CK as a non-systemic, dermal biomarker to prove SM exposures. In the present study we investigated the potential of alkylated CK as a biomarker using the following approach: initially, the expression of CK in rat and human skin was shown by Western blot analysis. Next, rat and human skin samples were exposed ex vivo to SM followed by the extraction of $\mathrm{CK}$ applying immunomagnetic separation (IMS). Afterwards, micro liquid chromatography-electrospray ionization high-resolution tandem-mass spectrometry ( $\mu$ LC-ESI MS/HRMS) was used to identify the adduct formation at $\mathrm{Cys}^{282}$ of human and rat $\mathrm{CK}$ ex vivo. Finally, an in vivo animal study was conducted to evaluate the suitability of the HETE-CK biomarker and compare it to the already established HETE-albumin- and HETE-DNAderived biomarkers.

\section{Materials and methods}

\section{Chemicals}

SM was provided by the German Ministry of Defense. Integrity and purity (at least 99\%) were shown by in-house nuclear magnetic resonance (NMR) spectroscopy. Decontaminant 
(reactive skin decontamination lotion, RSDL) was also provided by the German Ministry of Defense. Alkaline phosphatase, benzonase, DNase, iodoacetamide (IAA), dimethyl pimelimidate (DMP), Tween20, phosphate-buffered saline (PBS), Tris base (TRIS), triethanolamine (TEA) buffer, ethanol $(\mathrm{EtOH})$, benzonase, sodium acetate $(\mathrm{NaOAc})$ and alkaline phosphatase (AP) were purchased by Sigma-Aldrich (Steinheim, Germany). Thiourea, urea, 3-[(3-cholamidopropyl)dimethylammonio]-1-propanesulfonate (CHAPS), protein inhibitor mix, nuclease mix, 2D-Quant Kit for protein quantification and dithiothreitol (DTT) were provided by GE Healthcare (Chicago, IL, USA). Phosphodiesterase (PDE), Dynabeads $^{\mathrm{TM}}$ Protein G, 4-12\% bis-tris gels, NuPAGE SDS MES running and transfer buffers, and polyvinylidene fluoride (PVDF) membranes were obtained from Thermo Fisher Scientific (Waltham, USA). Proteinase K (ProtK), water (LC-MS-grade), formic acid (FA, 98-100\%) and $\mathrm{MgCl}_{2}$ were delivered by Merck (Darmstadt, Germany). Triple-deuterated atropine $\left(\mathrm{d}_{3}\right.$-atropine) was purchased from CDN Isotopes (Pointe-Claire, Quebec, Canada) and $\mathrm{NH}_{4} \mathrm{HCO}_{3}$ (ultra-grade, $\geq 99.5 \%$ ) from Fluka (Buchs, Switzerland). $\mathrm{HCl}, \mathrm{NaCl}$ and $\mathrm{NaN}_{3}$ were obtained from Carl Roth (Karlsruhe, Germany). Rabbit monoclonal anti-CK B-type, mouse monoclonal anti-CK M-type and mouse monoclonal anti-CK MB-type antibodies were purchased from Abcam (Cambridge, UK). As secondary antibodies, IRDye ${ }^{\circledR} 800 \mathrm{CW}$ goat anti-rabbit IgG and IRDye ${ }^{\circledR} 800 \mathrm{CW}$ goat anti-mouse IgG were used (LI-COR Biosciences, Bad Homburg, Germany).

\section{Skin origin for ex vivo experiments}

Ratskin flaps were derived from study-independent ex vivo or in vivo experiments (all approved by the animal welfare commission) and were kindly provided by the Bundeswehr Institute of Pharmacology and Toxicology (Munich, Germany). All human skin samples were taken from resectates that were obtained during operations and would otherwise have been discarded. This was approved by the ethics commission of the university hospital of Regensburg.

\section{Exposure of rat and human skin to SM ex vivo}

Skin biopsies with a diameter of $8 \mathrm{~mm}$ (approximately $50 \mathrm{~mm}^{2}$ ) were taken from ex vivo rat or human skin using a circular blade biopsy tool (DocCheck Shop, Cologne, Germany). Specimens were transferred into separate glass vials, aligned upwards with the epidermis facing to the top and $10 \mu \mathrm{L}$ of either neat SM $(12.7 \mathrm{mg})$ or of different ethanolic SM solutions (corresponding to absolute amounts of $0.00127,0.0127,0.127$, and $1.27 \mathrm{mg} \mathrm{SM}$ ) were added. The respective SM solution was applied as a single drop precisely on top of the epidermis, without additional contact of any other parts of the specimen. To generate blank samples, $10 \mu \mathrm{L} \mathrm{EtOH}$ was used instead of SM. After $1 \mathrm{~h}$ incubation at room temperature (RT) under a fume hood, $100 \mu \mathrm{L}$ RSDL was added to each vial to allow decontamination. After 15 min incubation, RSDL was discarded and samples were rinsed with deionized water. Each vial was gently agitated, and the supernatant was discarded. This procedure was repeated three-times before $500 \mu \mathrm{L}$ deionized water was added prior to homogenization. Exposure experiments were carried out using three independent skin samples $(n=3)$ for each concentration.

\section{Homogenization of skin, lysis, and determination of protein concentration}

The water covering the skin biopsies was removed and $1 \mathrm{~mL}$ lysis buffer (7 M urea, $2 \mathrm{M}$ thiourea, $4 \%$ w/v CHAPS, $40 \mathrm{mM}$ DTT, $10 \mu \mathrm{L}$ proteinase-inhibitor mix, $\mathrm{pH}$ 8.5) was added to each sample. Skin samples were homogenized using an T25 digital ultra-turrax system equipped with an $8 \mathrm{~mm}$ diameter dispersion tool (IKA®-Werke, Staufen, Germany). The glass vials containing the biopsies were placed on ice and subjected to 8 cycles with $10 \mathrm{~s}$ homogenization time at a maximum rotation speed. The tissue debris was removed by centrifugation for $20 \mathrm{~min}$ at $4{ }^{\circ} \mathrm{C}$ and 2,500 $\mathrm{RCF}$. Supernatants were transferred into a reaction vial and $5 \mu \mathrm{L}$ nuclease mix was added. Samples were then incubated for $60 \mathrm{~min}$ at RT. Still undissolved particles were discarded after centrifugation $\left(30 \mathrm{~min}, 4^{\circ} \mathrm{C}, 21,130 \mathrm{RCF}\right)$ and subsequent transfer of the supernatant into another reaction vial. Protein concentration was determined using the 2D-Quant Kit according to the manufacturer's instructions. Samples were frozen at $-20^{\circ} \mathrm{C}$ afterwards prior to further analysis.

\section{Western blot analysis}

A portion of the final protein solution (Sect. Homogenization of skin, lysis, and determination of protein concentration) containing $10 \mu \mathrm{g}$ protein was taken from each sample. After adding $2 \mu \mathrm{L}$ sample loading buffer (LI-COR Biosciences) and $6 \mu \mathrm{L}$ aqueous DTT solution $(80 \mathrm{mg} / \mathrm{mL})$, water was added to obtain a final volume of $25 \mu \mathrm{L}$. Samples were boiled at $95{ }^{\circ} \mathrm{C}$ for $5 \mathrm{~min}$ to reduce and denature the proteins. Afterwards, $10 \mu \mathrm{g}$ protein was loaded per lane on precast polyacrylamide gel electrophoresis (PAGE) gradient gels (4-12\% bis-tris gel). A molecular weight marker (Chameleon Duo pre-stained protein ladder 8-260 kDa, LI-COR Biosciences) was loaded to one lane per gel. SDS-PAGE in NuPAGE SDS MES running buffer was performed for $45 \mathrm{~min}$ at $180 \mathrm{~V}$. Afterwards, proteins were blotted onto a PVDF membrane that was activated with methanol for $1 \mathrm{~min}$ before. The wet transfer was performed in a mini blot module (ThermoFisher Scientific) 
for $1 \mathrm{~h}$ at $20 \mathrm{~V}$ using NuPAGE transfer buffer. The PVDF membrane was blocked with PBS blocking buffer (LI-COR Biosciences) for $1 \mathrm{~h}$ at RT. Membranes were incubated overnight at $4{ }^{\circ} \mathrm{C}$ with either anti-CK B-, anti-CK M- or anti-CK MB-type antibodies diluted 1:1,000 in PBST $(0.2 \% \mathrm{v} / \mathrm{v}$ Tween 20 in PBS $)$. Afterwards, membranes were washed three times for 10 min each with PBST, and then appropriately incubated with either goat-anti-rabbit $800 \mathrm{CW}$ or goat-anti mouse $800 \mathrm{CW}$ secondary antibody $(1: 15,000$ dilution of $1 \mathrm{mg} / \mathrm{mL}$ in PBS blocking buffer with $0.2 \% \mathrm{v} / \mathrm{v}$ Tween 20 ) for $1 \mathrm{~h}$ at RT. After three times washing with PBST, blots were scanned on a LI-COR odyssey scanner (LI-COR) in automatic mode.

\section{Purification of CK from skin lysates by IMS and proteolysis}

A portion of $500 \mu \mathrm{L}$ of the commercially available magnetic Dynabead slurry was transferred into a reaction vial to remove the liquid layer on a magnet stand. Beads were washed with $1 \mathrm{~mL}$ PBST for three times. Afterwards, beads were incubated with $140.8 \mu \mathrm{L}$ anti-CK B-type antibody solution in PBST $(0.71 \mathrm{mg} / \mathrm{mL})$ and $2 \mathrm{~mL}$ PBST for $15 \mathrm{~min}$ at RT on a nutating mixer. After removal of the supernatant, beads were washed twice with $1 \mathrm{~mL}$ TEA buffer (200 mM TEA and $0.025 \% \mathrm{v} / \mathrm{v} \mathrm{NaN}_{3}$ dissolved in water). Finally, $1 \mathrm{~mL}$ DMP-solution $(5.4 \mathrm{mg} / \mathrm{mL}$ in TEA buffer) was added. The mixture was incubated for $30 \mathrm{~min}$ at RT on a nutating mixer. The supernatant was removed, and $1 \mathrm{~mL}$ TBS (200 mM Tris- $\mathrm{HCl}, 9 \% \mathrm{w} / \mathrm{v} \mathrm{NaCl}$ ) was added for a 15 min incubation. After two washing steps with $500 \mu \mathrm{L}$ PBST, beads were suspended in $475 \mu \mathrm{L}$ PBS and stored at $4{ }^{\circ} \mathrm{C}$.

For each IMS step, $50 \mu \mathrm{L}$ of the labeled bead suspension in PBS was incubated with $2 \mathrm{mg}$ protein sample for $24 \mathrm{~h}$ at $4{ }^{\circ} \mathrm{C}$ on nutating mixer. Afterwards, the supernatant was removed, and beads were washed twice with $500 \mu \mathrm{L}$ PBST. Beads were suspended in $100 \mu \mathrm{L}$ IAA-solution (40 mM IAA in HPLC-water) for $30 \mathrm{~min}$ and washed twice with $500 \mu \mathrm{L}$ PBST. After removing the washing solution, $10 \mu \mathrm{L}$ ProtK solution $\left(15 \mathrm{mg} / \mathrm{mL}\right.$ in $50 \mathrm{mM} \mathrm{NH}_{4} \mathrm{HCO}_{3}$ ) and $75 \mu \mathrm{L}$ water were added to incubate for $2 \mathrm{~h}$ at $50{ }^{\circ} \mathrm{C}$ in a thermal mixer. The liquid phase was transferred into an ultrafiltration (UF)-device with a molecular weight cut-off (MWCO) of $10 \mathrm{kDa}$ (Vivaspin 500 centrifugal concentrator, Sartorius Stedim, Göttingen, Germany) and centrifuged for $10 \mathrm{~min}$ at $10,000 \mathrm{RCF}$. A portion of $100 \mu \mathrm{L}$ $\mathrm{d}_{3}$-atropine solution ( $3 \mathrm{ng} / \mathrm{mL}$ in $0.5 \% \mathrm{v} / \mathrm{v} \mathrm{FA}$ ) was added as internal standard and samples were ultrafiltrated for $10 \mathrm{~min}$ at 10,000 RCF. The filtrate was transferred into a glass vial and stored at $4{ }^{\circ} \mathrm{C}$ for MS analysis.

\section{In vivo animal study}

Male Wistar rats (9-10 weeks old, weighing 275-300 g) were obtained from Charles River Germany (Sulzfeld, Germany). Animals were kept under standard housing conditions, with food and water ad libitum, controlled temperature/humidity and a 12/12 h light/dark cycle. All experimental procedures were approved by the commission for protection of animal welfare as well as authorities of the Bundeswehr (Gz 42-34-30-20/G03-18) and were in accordance with the German Animal Welfare Act (BGBl. I S. 1206 , 1313; May 18th, 2006) and the European Council Directive 2010/63/EU (September 22nd, 2010). Prior to experimentation, animals were allowed a 7-days acclimatization period to reduce stress from transport. On the day of the experiment, animals were anesthetized by intraperitoneal injection of a mixture containing ketamine $(75 \mathrm{mg} / \mathrm{kg}$ body weight, b.w., Ketavet $100 \mathrm{mg} / \mathrm{mL}$, zoetis Deutschland $\mathrm{GmbH}$, Berlin, Germany) and xylazine (10 mg/kg b.w., Xylasel $20 \mathrm{mg} /$ $\mathrm{mL}$, Selectavet Dr. Otto Fischer GmbH, Weyarn-Holzolling, Germany). Sufficient depth of anesthesia during the experiment was determined by checking the hind-paw withdrawal reflex. If reflexes were evident, an additional injection with $2 / 3$ of the initial anesthesia dose was administered intraperitoneally. For SM exposure, animals were positioned back facing upwards on a heated operating table and the fur in a $3 \times 5 \mathrm{~cm}$ rectangle on the back was trimmed with a shearing machine, cutting the hair to about $2 \mathrm{~mm}$ length. Afterwards, the skin was cleaned with water, dried, and two adhesive strips both containing a pre-cut of $8 \mathrm{~mm}$ diameter each were attached at distant sites of the skin. Both areas were then exposed with 12.7, 31.8, 63.6, 95.4 or $127 \mathrm{mg}$ of neat SM $(8 \mathrm{M})$ for $1 \mathrm{~h}$. Each concentration was applied to three animals ( $n=3$ per concentration). As a negative control, one animal was exposed the same way to $100 \mu \mathrm{L} \mathrm{EtOH}$ for $1 \mathrm{~h}$. The exposed skin areas were covered with plastic caps after administration of SM or EtOH to prevent evaporation. After $1 \mathrm{~h}$, the plastic caps were removed, and the skin was decontaminated using RSDL. While still under anesthesia, animals were then euthanized by cardiac puncture. EDTA blood was collected centrifuged $\left(20 \mathrm{~min}, 4{ }^{\circ} \mathrm{C}, 500 \mathrm{RCF}\right)$ and plasma was isolated for MS analysis of adducted rat serum albumin (RSA, see Plasma sample preparation and $\mu \mathrm{LC}$-ESI MS/ HRMS analysis of C(-HETE)PY). The SM-exposed skin areas were taken using $8 \mathrm{~mm}$ punches and stored at $4{ }^{\circ} \mathrm{C}$ until further processing for DNA- and CK-adduct analysis.

\section{$\mu L C-E S I$ MS/HRMS system}

For the investigation of alkylated proteins and DNA micro liquid chromatography-electrospray ionization high-resolution tandem-mass spectrometry ( $\mu$ LC-ESI MS/HRMS) measurements were performed using a hybrid quadrupole 
time-of-flight mass spectrometer $\left(\mathrm{TT} 5600^{+}, \mathrm{ABSciex}\right.$, Darmstadt, Germany) online coupled to a microLC 200 pump (Eksigent Technologies LLC, Dublin, CA, USA) combined with an HTX-xt DLW autosampler (CTC Analytics, Zwingen, Switzerland) equipped with a $20 \mu \mathrm{L}$ sample loop (Sunchrom, Friedrichsdorf, Germany). The sample tray was kept at $15{ }^{\circ} \mathrm{C}$. The entire system was controlled by the Eksigent 4.2 (Eksigent Technologies LLC) and the Analyst TF 1.7.1 (ABSciex) software. All separations targeting either the alkylated CK-derived tetrapeptide TC(-HETE) PS or the albumin-derived alkylated tripeptide C(-HETE) PY or the DNA-derived alkylated bases HETE-Gua, HETEAde and Gua-ETE-Gua were carried out at $45{ }^{\circ} \mathrm{C}$ on an ACQUITY UPLC HSS T3 column $(\mathrm{C} 18,50 \mathrm{~mm} \times 1.0 \mathrm{~mm}$ I.D., $1.8 \mu \mathrm{m}, 100 \AA$ A, Waters, Eschborn, Germany) protected by a security guard ultra-cartridge (C18-peptide, Phenomenex, Aschaffenburg, Germany). Binary mobile phase gradients (see below) were used consisting of solvent $\mathrm{A}(0.05 \%$ $\mathrm{v} / \mathrm{v}$ FA) and solvent B (acetonitrile/ $\mathrm{H}_{2} \mathrm{O}$ 80:20 v/v, 0.05\% v/v FA).

\section{Skin sample preparation and $\mu$ LC-ESI MS/HRMS analysis of TC(-HETE)PS}

Samples of human and rat skin ex vivo exposed to SM as well as rat skin obtained from one skin biopsy per animal from the in vivo experiments were homogenized (Sect. Homogenization of skin, lysis, and determination of protein concentration). CK was purified by IMS and digested by ProtK (Sect. Purification of CK from skin lysates by IMS and proteolysis) before MS/HRMS analysis. For $\mu$ LC-ESI MS/HRMS analysis of the alkylated tetrapeptide TC(-HETE)PS the following gradient of solvent $\mathrm{A}$ and solvent B (Sect. $\mu$ LC-ESI MS/HRMS system) was applied at a flow of $30 \mu \mathrm{L} / \mathrm{min}: t[\mathrm{~min}] / \mathrm{B}[\%]$ : 0/0; 11/35; 11.5/95; $13.5 / 95 ; 14 / 0 ; 15 / 0$ at $45{ }^{\circ} \mathrm{C}$ including an initial equilibration time of $5 \mathrm{~min}$. Productions of protonated TC(-HETE)PS $\left([\mathrm{M}+\mathrm{H}]^{+}: m / z\right.$ 511.2) and protonated $\mathrm{d}_{3}$-atropine $\left([\mathrm{M}+\mathrm{H}]^{+}\right.$ $\mathrm{m} / \mathrm{z}$ 293.1) were monitored using the following MS settings: curtain gas (CUR) 30 psi $\left(2.1 \cdot 10^{5}\right.$ bar), heater gas (GS1) 40 psi (2.8.10 bar), turbo ion spray gas (GS2) $50 \mathrm{psi}$ (3.4.10 5 bar), temperature (TEM) $200{ }^{\circ} \mathrm{C}$, ion spray voltage floating (ISVF) $5.5 \mathrm{kV}$, ion release delay (IRD) $67 \mathrm{~ms}$, accumulation time $300 \mathrm{~ms}$, ion release width (IRW) $25 \mathrm{~ms}$, collision energy (CE) $45 \mathrm{~V}$ (alkylated tetrapeptide) and $42 \mathrm{~V}$ $\left(\mathrm{d}_{3}\right.$-atropine), collision energy spread (CES) $5 \mathrm{~V}$, and declustering potential (DP) $60 \mathrm{~V}$.

\section{Skin sample preparation and $\mu$ LC-ESI MS/HRMS analysis of HETE-Gua, HETE-Ade and Gua-ETE-Gua}

One skin biopsy per animal was used to extract DNA. The skin biopsy was trimmed to $25 \mathrm{mg}$ by removing adherent fat tissue. DNA was extracted using the QIAamp DNA Mini Kit from Qiagen (Hilden, Germany) according to the manufacturer's protocol. In brief, specimens were manually cut into small pieces, transferred into a $1.5 \mathrm{~mL}$ reaction vial, and immersed in $180 \mu \mathrm{L}$ ATL buffer (Qiagen). Then, $20 \mu \mathrm{L}$ ProtK solution $\left(20 \mathrm{mg} / \mathrm{mL}\right.$ in $\left.50 \mathrm{mM} \mathrm{NH}_{4} \mathrm{HCO}_{3}\right)$ was added and the samples were incubated at $56{ }^{\circ} \mathrm{C}$ for $4 \mathrm{~h}$. After centrifugation, $4 \mu \mathrm{L}$ RNase A (100 mg/mL, Qiagen) was added and samples were further incubated for $2 \mathrm{~min}$ at RT. AL buffer $(200 \mu \mathrm{L}$, Qiagen) was added to the sample and incubated at $70{ }^{\circ} \mathrm{C}$ for $10 \mathrm{~min}$. After adding $200 \mu \mathrm{L} \mathrm{EtOH}$, the mixture was vortexed and applied to a QIAamp Mini spin column (Qiagen) and centrifuged for 1 min at 6,000 RCF. The eluate was discarded, and the column was washed twice with $500 \mu \mathrm{L}$ washing buffer (Qiagen) each. The DNA was eluted by the addition of $200 \mu \mathrm{L}$ buffer AE (Qiagen) to the column and subsequent centrifugation at $6,000 \mathrm{RCF}$ for $1 \mathrm{~min}$. The DNA eluate was digested by adding of $3.9 \mu \mathrm{L}$ of $10 \times$ digestion master mix consisting of $17 \mu \mathrm{L}$ of $630 \mathrm{mM}$ Tris buffer, $\mathrm{pH} 8$, and $63 \mathrm{mM} \mathrm{MgCl}_{2}, 2 \mu \mathrm{L}$ benzonase (10 U/ $\mu \mathrm{L})$ and $20 \mu \mathrm{L}$ DNAse $(2 \mathrm{mg} / \mathrm{mL})$. Samples were incubated at $37{ }^{\circ} \mathrm{C}$ for $2 \mathrm{~h}$. Afterwards, $1.3 \mu \mathrm{L} \mathrm{NaOAc}(1 \mathrm{M}, \mathrm{pH} 7.8)$, $0.5 \mu \mathrm{L} \mathrm{AP}(10 \mathrm{U} / \mu \mathrm{L})$ and $0.5 \mu \mathrm{L} \mathrm{PDE}(0.5 \mathrm{U} / \mu \mathrm{L})$ were added and the mixture was incubated for $2 \mathrm{~h}$ at $37^{\circ} \mathrm{C}$. The incubated samples were transferred into an UF-device with a MWCO of $10 \mathrm{kDa}$ and centrifuged for $10 \mathrm{~min}$ at 10,000 RCF and $15^{\circ} \mathrm{C}$. Then, $100 \mu \mathrm{L}$ water was added followed by centrifugation ( $\left.10 \mathrm{~min}, 10,000 \mathrm{RCF}, 15^{\circ} \mathrm{C}\right)$. The filtrate was heated to $90{ }^{\circ} \mathrm{C}$ for $20 \mathrm{~min}$. For subsequent $\mu \mathrm{LC}$-ESI MS/ HRMS analysis, an aliquot was diluted 1:3 with $\mathrm{d}_{3}$-atropine solution ( $3 \mathrm{ng} / \mathrm{mL}$, in $0.5 \% \mathrm{v} / \mathrm{v} \mathrm{FA})$. Alkylated nucleotides were separated at $50 \mu \mathrm{L} / \mathrm{min}$ applying a gradient of solvent A and B (Sect. $\mu$ LC-ESI MS/HRMS system): $t$ [min]/B [\%]: $0 / 2 ; 3 / 60 ; 4.98 / 60 ; 5.0 / 2 ; 6.0 / 2$ at $60{ }^{\circ} \mathrm{C}$ including an initial equilibration time of $3 \mathrm{~min}$ with $100 \mu \mathrm{L} / \mathrm{min}$. Protonated HETE-Gua $\left([\mathrm{M}+\mathrm{H}]^{+} m / z, 256.1\right)$, HETE-Ade $\left([\mathrm{M}+\mathrm{H}]^{+}\right.$ $m / z$ 240.1), Gua-ETE-Gua $\left([\mathrm{M}+\mathrm{H}]^{+} m / z\right.$ 389.1) and $\mathrm{d}_{3}$-atropine $\left([\mathrm{M}+\mathrm{H}]^{+} \mathrm{m} / \mathrm{z}, 293.1\right)$ were monitored in product ion scan mode applying the following MS settings: CUR $30 \mathrm{psi}\left(2.1 \cdot 10^{5}\right.$ bar), GS1 $50 \mathrm{psi}\left(3.4 \cdot 10^{5} \mathrm{bar}\right)$, GS2 $50 \mathrm{psi}$ (3.4.10 5 bar), TEM $300{ }^{\circ} \mathrm{C}$, ISVF $5.0 \mathrm{kV}$, IRD $67 \mathrm{~ms}$, accumulation time $50 \mathrm{~ms}$, IRW $25 \mathrm{~ms}$, CE $22 \mathrm{~V}$ (HETE-Gua), $20 \mathrm{~V}$ (HETE-Ade), $25 \mathrm{~V}$ (Gua-ETE-Gua), CES 5 V (HETEGua and HETE-Ade), 10 V (Gua-ETE-Gua) and DP 65 V.

\section{Plasma sample preparation and $\mu$ LC-ESI MS/HRMS analysis of C(-HETE)PY}

Rat plasma $(100 \mu \mathrm{L})$ obtained from the in vivo experiments (Sect. In vivo animal study) was mixed with $50 \mathrm{mM}$ $\mathrm{NH}_{4} \mathrm{HCO}_{3}(300 \mu \mathrm{L}, \mathrm{pH}$ 8) and ProtK solution $(100 \mu \mathrm{L}$, $20 \mathrm{mg} / \mathrm{mL}$ in $50 \mathrm{mM} \mathrm{NH}_{4} \mathrm{HCO}_{3}$ ). After incubation at $50{ }^{\circ} \mathrm{C}$ for $4 \mathrm{~h}$ and $\mathrm{UF}\left(10 \mathrm{~min}, 15^{\circ} \mathrm{C}, 10,000 \mathrm{RCF}\right)$, samples were 
diluted $1: 3$ with $\mathrm{d}_{3}$-atropine solution $(3 \mathrm{ng} / \mathrm{mL}$ in $0.5 \% \mathrm{v} / \mathrm{v}$ FA). For $\mu L C$-ESI MS/HRMS analysis the gradient of solvent $\mathrm{A}$ and solvent $\mathrm{B}$ (Sect. $\mu \mathrm{LC}$-ESI MS/HRMS system) at $40{ }^{\circ} \mathrm{C}$ was as follows: $t$ [min]/B [\%]: 0/2;11/30; 11.5/95; $13.5 / 95 ; 14 / 2 ; 15 / 2$ with a flow of $30 \mu \mathrm{L} / \mathrm{min}$ including an initial equilibration time of 5 min with $30 \mu \mathrm{L} / \mathrm{min}$ and starting composition ( $2 \% \mathrm{v} / \mathrm{v} \mathrm{B})$. The mass spectrometer operated in the product ion scan mode monitoring product ions of the protonated, alkylated, RSA-derived tripeptide C(-HETE)PY $\left([\mathrm{M}+\mathrm{H}]^{+}: \mathrm{m} / \mathrm{z}, 486.2\right)$ and protonated $\mathrm{d}_{3}$-atropine using the following parameters: CUR $30 \mathrm{psi}\left(2.1 \cdot 10^{5} \mathrm{bar}\right), \mathrm{GS} 140 \mathrm{psi}$ $\left(2.8 \cdot 10^{5}\right.$ bar), GS2 $50 \mathrm{psi}\left(3.4 \cdot 10^{5} \mathrm{bar}\right)$, TEM $200{ }^{\circ} \mathrm{C}$, ISVF $5.5 \mathrm{kV}$, IRD $67 \mathrm{~ms}$, accumulation time: $300 \mathrm{~ms}$, IRW $25 \mathrm{~ms}$, CE $35 \mathrm{~V}$, CES $5 \mathrm{~V}$, and DP $60 \mathrm{~V}$.

\section{Results and discussion}

\section{Detection of CK from rat and human skin by Western blot analysis}

The molecular weight of the monomeric CK is approximately $43 \mathrm{kDa}$ with slight variations between diverse species (Perryman et al. 1983). Western blot analysis under reducing conditions using antibodies directed against either the M-, $\mathrm{B}$-, or MB-type of CK revealed that the B-type CK was predominately expressed in the rat (Fig. 1a) as well as in human skin (Fig. 1b). These findings are in accordance with the results presented by Schlattner et al. describing B-type CK as the most prominent isoform in murine skin (Schlattner et al. 2002) and those of Lenz et al. reporting on the expression of B-type CK in human skin (Lenz et al. 2005).

\section{Detection of CK alkylation in rat skin ex vivo}

Based on the positive Western blot results, rat skin was exposed to $12.7 \mathrm{mg}$ SM $(10 \mu \mathrm{L}$ of neat SM applied on a surface of approximately $50 \mathrm{~mm}^{2}$ ) ex vivo and analyzed for HETE-CK adduct formation. As reported previously by our group, SM alkylates the reactive $\mathrm{Cys}^{282}$ residue in human CK (Lüling et al. 2020). However, after lysis of SM-exposed rat skin samples and direct subsequent proteolysis with ProtK and analysis by $\mu$ LC-ESI MS/HRMS the expected alkylated CK-derived tetrapeptide TC(-HETE)PS was not detected. It was assumed that the failed detection was due to the low CK concentrations in the prepared samples, which were insufficient for MS-analysis without any concentration step. Therefore, we developed an IMS method well-suited for the extraction and enrichment of CK from skin lysates using the rabbit monoclonal anti-CK B-type antibody. After application of the IMS procedure, the expected alkylated CK-derived biomarker tetrapeptide was detected and identified by $\mu$ LC-ESI MS/HRMS (Fig. 2a, b). Product ions

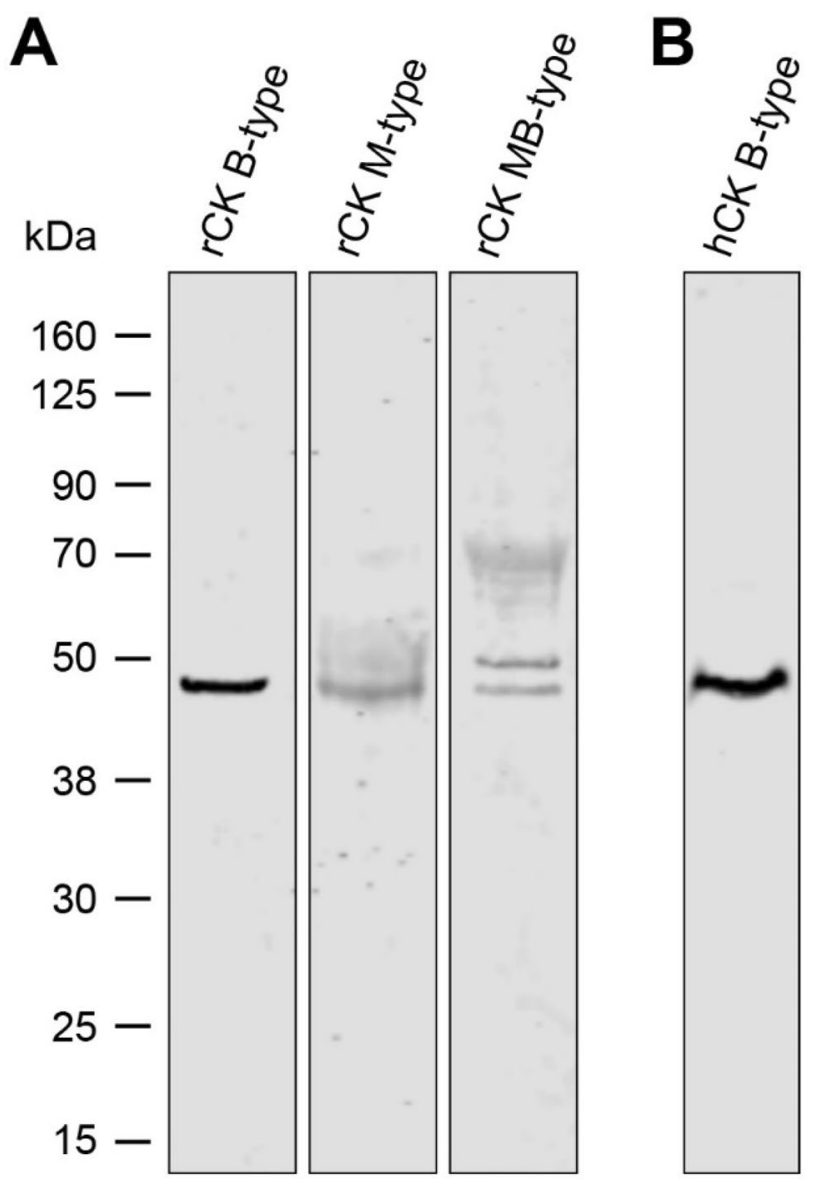

Fig. 1 Western blot analyses of creatine kinase (CK) in ex vivo skin samples. a Screening for the three different isoenzymes of $\mathrm{CK}$ in rat skin using monoclonal anti-CK antibody targeting either the B-, M- or MB-type isoform. The CK B-type monomer with a molecular weight of approximately $43 \mathrm{kDa}$ was found as the most abundant isoenzyme in rat skin. b Expression of the B-type isoform was also detected in human skin lysates

detected were the same as already described and assigned recently (Lüling et al. 2020). Corresponding analysis of blank rat skin not exposed to SM did not show any interferences (Fig. 2c). The technical lower limit of detection (LOD), describing the lowest amount of SM used to expose rat skin biopsies $\left(8 \mathrm{~mm}\right.$ diameter corresponding to $50 \mathrm{~mm}^{2}$ skin area) ex vivo that still allowed the $\mu$ LC-ESI MS/HRMS detection of the alkylated tetrapeptide biomarker, was estimated by dose-response experiments and found to correspond to $127 \mu \mathrm{g}$ SM.

\section{Detection of CK alkylation in human skin ex vivo}

The primary structure of rat (NCBI Reference Sequence NP_036661.3) and human CK B-type (NCBI Reference Sequence: NP_001814.2) exhibit a 100\% identity as determined by the Constraint-based Multiple Alignment Tool 


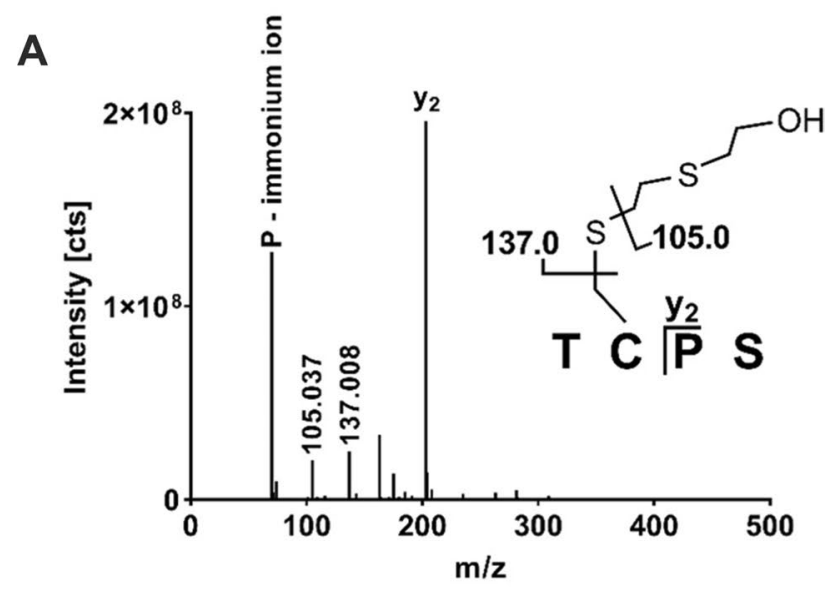

B

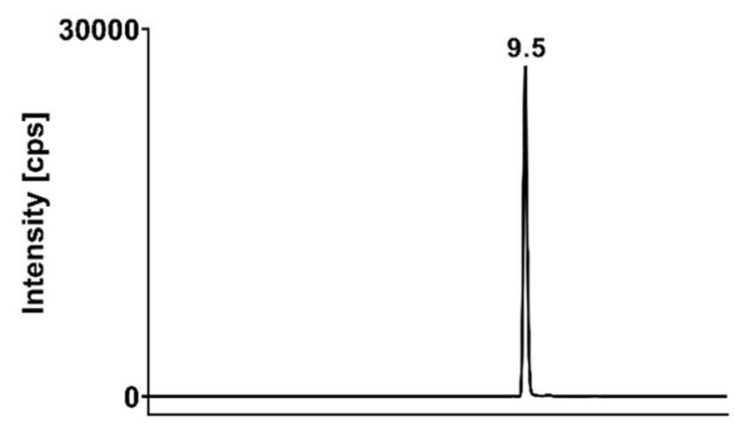

C

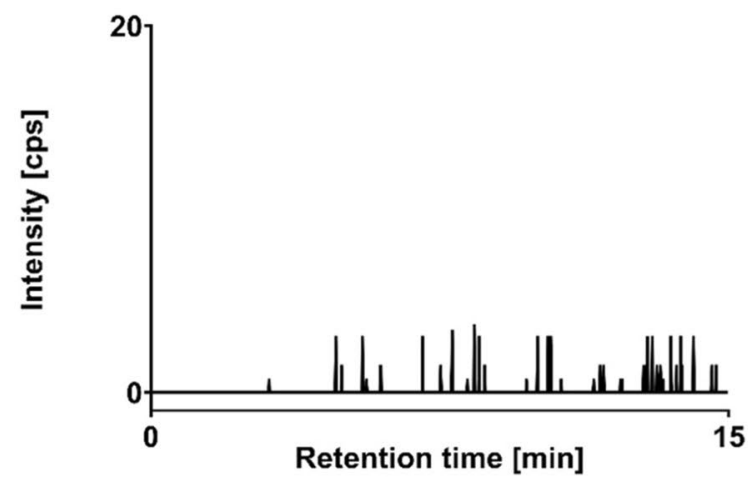

Fig. $2 \mu$ LC-ESI MS/HRMS analyses of TC(-HETE)PS from rat skin exposed to SM. Ratskin was lysed, CK was extracted by IMS and subjected to proteolysis with ProtK. a MS/HRMS spectrum of the alkylated CK-derived tetrapeptide TC(-HETE)PS $(\mathrm{m} / \mathrm{z}$ 510.896, single protonated) extracted from the $\mu$ LC-ESI MS/HRMS run peak depicted in Figure part B. b Extracted ion chromatogram (XIC) of TC(-HETE)PS derived from rat skin exposed to SM. For reasons of clarity only the trace of the product ion at $\mathrm{m} / \mathrm{z} 137.008 \pm 0.005$ is illustrated. $\mathbf{c}$ XIC of TC(-HETE)PS of a prepared rat skin blank sample not exposed to SM showing no interferences

(COBALT) (Papadopoulos and Agarwala 2007), Therefore, we also expected the formation of the CK-adduct in human skin. Accordingly, we succeeded in the detection of the biomarker TC(-HETE)PS in samples from human skin exposed to SM ex vivo. The corresponding MS/HRMS spectrum was identical to that obtained from rat CK (Fig. 2a) thus confirming the identity of the biomarker. Therefore, we concluded that $\mathrm{CK}$, in general might represent a novel and valuable biomarker of SM exposure in humans and rat.

\section{In vivo animal study}

Results discussed above suggest the HETE CK-adduct as a marker protein not only for ex vivo but also for in vivo exposure scenarios. The adduct-derived tetrapeptide might represent a beneficial marker to document the exposure of a defined area on the skin (local biomarker) in contrast to marker proteins such as HETE-HSA (Noort et al. 1999; Gandor et al. 2015; John et al. 2016; Steinritz et al. 2016), HETE-hemoglobin (Noort et al. 1996; Black et al. 1997) or HETE-DNA from blood cells (Dębiak et al. 2011; Zubel et al. 2018, 2019) that provide evidence for systemic exposure. Therefore, an animal study investigating rats exposed to different concentrations of SM was carried out monitoring the different local (HETE-CK and HETE-DNA from skin cells) and the systemic adducts (HETE-RSA). Animals were exposed at two distant sites with identical doses of SM allowing analysis of HETE-DNA-adducts from one site and of HETE-CK at the other site.

\section{Detection of HETE-CK adducts in rat skin in vivo}

All SM doses applied resulted in the local formation of the HETE-CK adduct (Fig. 3). However, the correlation between the SM amount applied and the peak area of the TC(-HETE)PS biomarker extracted from a defined area of the skin $\left(50 \mathrm{~mm}^{2}\right)$ was rather less obvious. Most presumably this effect might be due to rapid and extensive diffusion processes of SM in the perfused skin of the living rat after challenging a prefixed skin area. Moreover, an unknown amount of the applied SM may have been absorbed in subdermal fat tissue thereby bypassing a reaction with epidermal CK. However, the CK-derived tetrapeptide served as a reliable qualitative local biomarker of the skin in all animals independent of the SM dose applied thus underlining the high chemical reactivity with $\mathrm{CK}$ and its suitability as a marker protein.

\section{Detection of HETE-DNA adducts in rat skin in vivo}

The digested DNA was analyzed to monitor HETE-Gua, HETE-Ade and the crosslinked Gua-ETE-Gua biomarkers (Zubel et al. 2019). MS/HRMS spectra (data not shown) confirmed the identity of the adducts corresponding to data published recently (Zubel et al. 2019). The most prominent product ion produced by the three biomarkers was the 


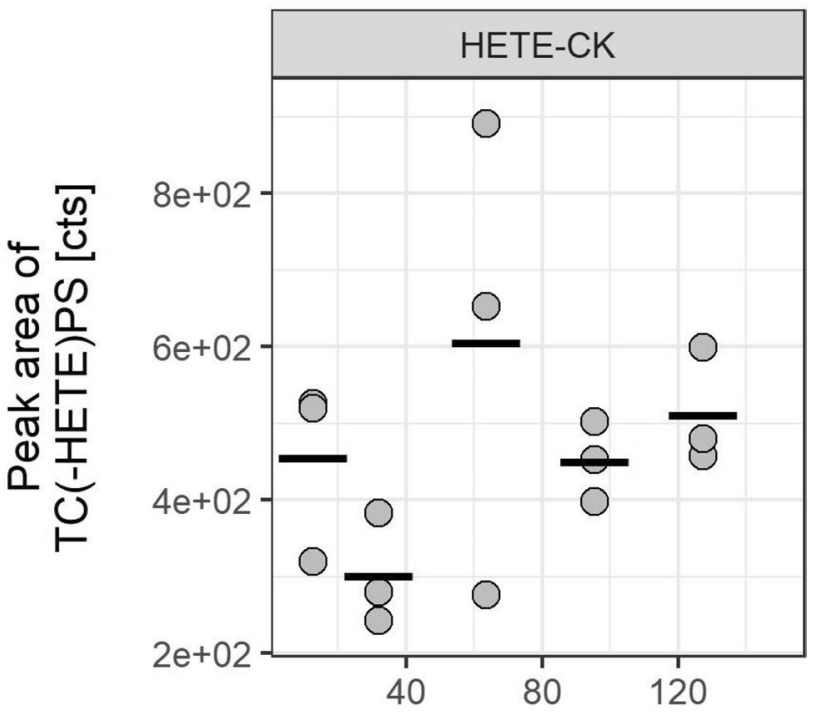

$\mathrm{SM}[\mathrm{mg}]$

Fig. 3 Peak areas of the alkylated CK-derived tetrapeptide TC(HETE)PS obtained from $\mu$ LC-ESI MS/HRMS analyses of rat skin exposed to SM in vivo. Skin samples were prepared postmortem by lysis, IMS to extract CK B-type, proteolysis of the protein with ProtK and final UF. An adduct formation was observed in each group, qualitatively proving the exposure. In vivo exposure experiments were carried out in triplicates $(n=3)$. Data points represent the individual values related to each animal and the bars provide the means of triplicate measurements
HETE-moiety $(\mathrm{m} / \mathrm{z}$ 105.037). Accordingly, this ion was used to follow the relative concentration profiles of the markers depending on the dose of SM administered. The dose-response relationship of SM-DNA adduct formation in rat skin followed a reverse parabola shape (Fig. 4).

The decrease of the peak areas of nucleic acid-adducts after reaching a maximum at a certain SM concentration might be indicative for an increasing extent of cross-links between the respective nucleobase and either other DNAbases or proteins, or for the prolongation of the attached modification by SM-induced alkylation of an already attached HETE-moiety. However, more plausible it might also be assumed that the larger extent of DNA crosslinks caused by higher SM doses may impact the sample preparation procedure by potentially deteriorating extraction and digest, thus reducing the concentration of the analyte. This has also been observed by Moser et al. who reported difficulties arising from the presence of $30 \mu \mathrm{M}$ SM and above in the detection of DNA strand breaks in peripheral blood leukocytes (Moser et al. 2004). Kehe et al. reported a similar effect when using a standard Comet assay to detect SM-induced DNA damages in a keratinocyte cell line and assumed increased DNA crosslinks that prevented migration in the electrical field (Kehe et al. 2009a). In an in vivo study, conducted by Zhang et al., rabbits were dermally exposed to SM doses of $2-15 \mathrm{mg} / \mathrm{kg}$ b.w. and the formation of SM-DNA adducts in urine was investigated (Zhang et al. 2014). The authors successfully detected alkylation of the respective nucleotides at all SM doses, but the percentage of SM-DNA adducts after exposure to $15 \mathrm{mg} / \mathrm{kg}$ b.w. SM was significantly lower compared to the $5 \mathrm{mg} / \mathrm{kg}$ b.w. SM

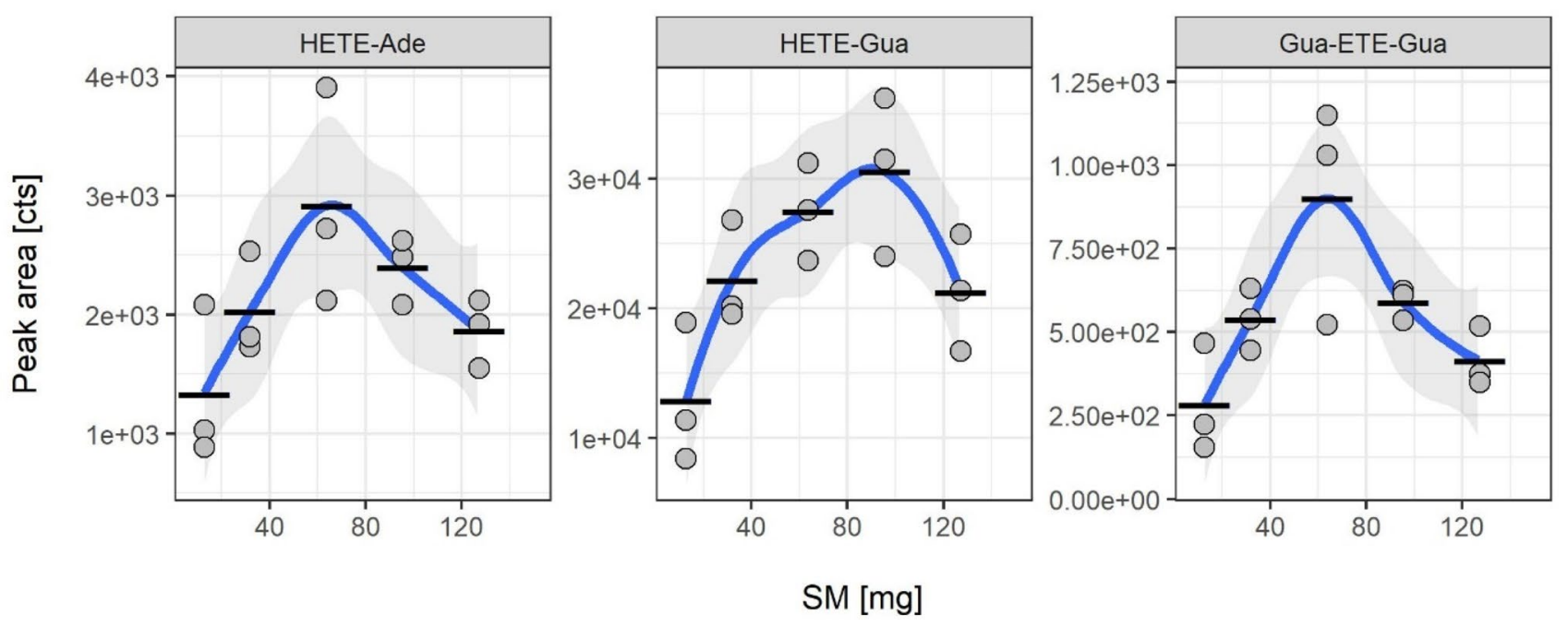

Fig. 4 Peak areas of the alkylated DNA-derived nucleotides HETEAde, HETE-Gua and Gua-ETE-Gua obtained from $\mu$ LC-ESI MS/ HRMS analyses of rat skin exposed to SM in vivo. Ratskin specimens were trimmed to $25 \mathrm{mg}$. Samples were subsequently prepared by ProtK, DNAse, heat treatment, and UF prior to $\mu$ LC-ESI MS/HRMS analysis. In vivo exposure experiments were carried out in triplicate $(n=3)$. Data points represent the individual values related to each animal and the bars provides the means of triplicate measurements. The ribbon indicates the $95 \%$ confidence interval of the linear curve fit 
dose. Thus, although SM-DNA adducts are a valuable and frequently used tissue biomarker, its quantitative interpretation is limited when used in high dose exposure scenarios.

\section{Detection of HETE-albumin adducts from rat plasma}

The formation of HETE-RSA adducts after the challenge of rats with SM has been described by Noort et al. (2008). They introduced the alkylated tripeptide C(-HETE)PY as a reliable in vivo biomarker produced by proteolysis of the RSA-adduct (Noort et al. 2008). Therefore, this analyte was also monitored in the present study to document a potential systemic uptake of SM. The peak areas of the biomarker in $\mu \mathrm{LC}$-ESI MS/HRMS analysis correlated to the concentration of HETE-RSA present in vivo. In contrast to the findings for the local biomarkers derived from skin CK (Fig. 3) and skin DNA (Fig. 4) a concentration-dependent linear increase of the biomarker concentration was observed (Fig. 5). Blank plasma obtained from a rat not exposed to SM did not show any adduct and interferences in $\mu$ LC-ESI MS/HRMS analysis. The dose-response effect was similar to the experiments performed by our group in vitro (Gandor et al. 2015; John et al. 2016). The evidence of the albumin-adducts in plasma proved that SM, even when applied at low doses and for only $1 \mathrm{~h}$, has penetrated the skin and entered the circulation allowing its systemic distribution and adduct formation in the blood.

\section{Conclusion and outlook}

Due to this experimental study, CK or rather $\mathrm{Cys}^{282}$ in CK B-type was identified as a new dermal target of low and local SM exposures. To our knowledge, it is also the first time that HETE-albumin adducts, and HETE-DNA adducts were monitored simultaneously in an in vivo animal study.

The verification of exposure was possible using the HETEalbumin-, -DNA-, and -CK-derived biomarker. Alkylation of albumin, representing a systemic biomarker, was observed already after exposure to $25 \mathrm{mg} \mathrm{SM}$ applied on rat skin, underlining the value and significance of HETE-albumin adducts for verification purposes. Alkylation of DNA nucleotides in skin tissue, representing a local biomarker, was also detected at all SM-doses. However, at SM doses $>63 \mathrm{mg}$ (applied on an $8 \mathrm{~mm}^{2}$ skin area) the concentration of these biomarkers decreased. The correlation of the biomarker concentration to an estimated exposure dose may thus be hampered. The formation of HETE-CK adducts was proven already after $12.7 \mathrm{mg}$ SM applied on an $8 \mathrm{~mm}^{2}$ skin area. Compared to HETE-DNA adducts, a loss of sensitivity at increasing SM doses was not evident. Hence, HETE-CK adducts may be well suited when used as local biomarker in high-dose exposures. Future studies

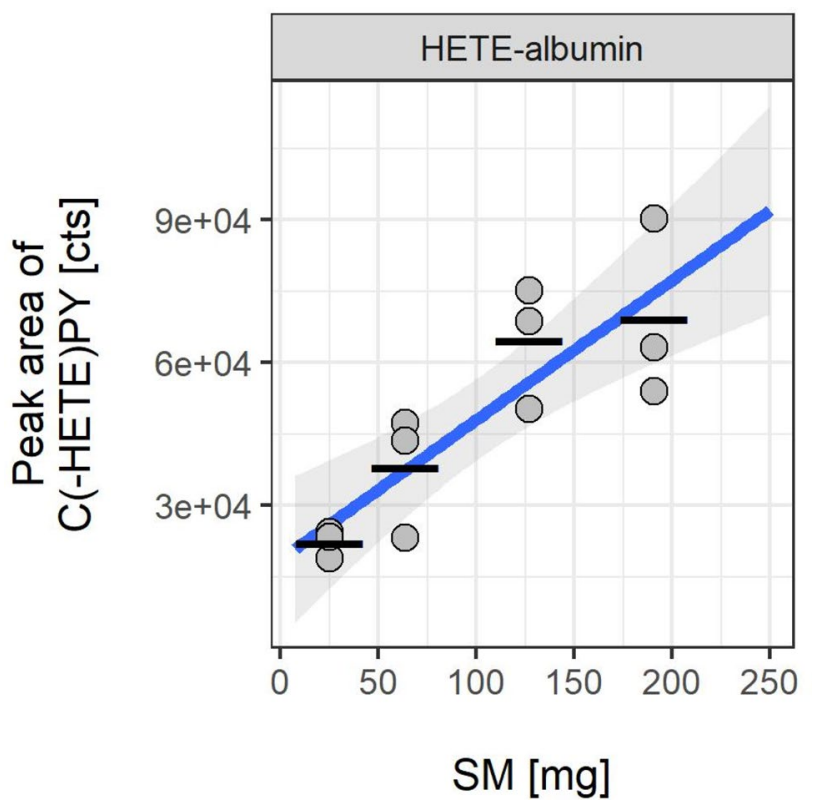

Fig. 5 Peak areas of the alkylated RSA-derived tripeptide C(-HETE) PY obtained from $\mu$ LC-ESI MS/HRMS analyses of rat plasma exposed to SM in vivo. Plasma samples were prepared by proteolysis with ProtK and UF. In vivo exposure experiments were carried out in triplicates $(n=3)$. Data points represent the individual values related to each animal and the bars provide the means of triplicate measurements. The ribbon indicates the $95 \%$ confidence interval of the linear curve

are planned to investigate dose-response relationships in more detail.

B-type CK, derived from epidermal cells, was detected in blister fluid that were provoked by shear stress (Paavonen et al. 1988; Kiistala et al. 1989). Since blister formation occurs in SM-induced skin injury (Kehe et al. 2009b) with accompanying cell death of affected keratinocytes (Rosenthal et al. 1998), these cells may release alkylated CK into the blister fluid. Hence, CK might also be considered as an additional biomarker in such biological specimens.

Acknowledgements The authors thank Marina Dentzel, Stefanie Oswald, and Ram Prasad for their excellent technical assistance.

Funding Open Access funding enabled and organized by Projekt DEAL. Part of the work was supported by the German Research Foundation (Deutsche Forschungsgemeinschaft, DFG, Research Training Group GRK 2338).

\section{Compliance with ethical standards}

Conflict of interest The authors declare no conflict of interest.

Open Access This article is licensed under a Creative Commons Attribution 4.0 International License, which permits use, sharing, adaptation, distribution and reproduction in any medium or format, as long as you give appropriate credit to the original author(s) and the source, 
provide a link to the Creative Commons licence, and indicate if changes were made. The images or other third party material in this article are included in the article's Creative Commons licence, unless indicated otherwise in a credit line to the material. If material is not included in the article's Creative Commons licence and your intended use is not permitted by statutory regulation or exceeds the permitted use, you will need to obtain permission directly from the copyright holder. To view a copy of this licence, visit http://creativecommons.org/licenses/by/4.0/.

\section{References}

Black RM, Harrison JM, Read RW (1997) Biological fate of sulphur mustard: in vitro alkylation of human haemoglobin by sulphur mustard. Xenobio Fate Foreign Compd Biol Syst 27(1):11-32. https://doi.org/10.1080/004982597240730

Dębiak M, Panas A, Steinritz D, Kehe K, Bürkle A (2011) Highthroughput analysis of DNA interstrand crosslinks in human peripheral blood mononuclear cells by automated reverse FADU assay. Toxicology 280(1-2):53-60. https://doi.org/10.1016/j. tox.2010.11.007

Gandor F, Gawlik M, Thiermann H, John H (2015) Evidence of sulfur mustard exposure in human plasma by LC-ESI-MS-MS detection of the albumin-derived alkylated HETE-CP dipeptide and chromatographic investigation of Its $\mathrm{Cis} /$ Trans isomerism. J Anal Toxicol 39(4):270-279. https://doi.org/10.1093/jat/bkv010

John H, Siegert M, Gandor F, Gawlik M, Kranawetvogl A, Karaghiosoff K, Thiermann H (2016) Optimized verification method for detection of an albumin-sulfur mustard adduct at Cys(34) using a hybrid quadrupole time-of-flight tandem mass spectrometer after direct plasma proteolysis. Toxicol Lett 244:103-111. https ://doi.org/10.1016/j.toxlet.2015.09.027

John H, Koller M, Worek F, Thiermann H, Siegert M (2019) Forensic evidence of sulfur mustard exposure in real cases of human poisoning by detection of diverse albumin-derived protein adducts. Arch Toxicol 93(7):1881-1891. https://doi.org/10.1007/s0020 4-019-02461-2

Kehe K, Müller H, Balszuweit F, Steinritz D, Thiermann H, Klaus SM, Kreppel H (2009a) New methods to detect sulfur mustard (SM) and SM-induced skin damage. In: Dishovsky C (ed) Counteraction to chemical and biological terrorism in East European countries. Springer, Dordrecht, pp 127-133

Kehe K, Thiermann H, Balszuweit F, Eyer F, Steinritz D, Zilker T (2009b) Acute effects of sulfur mustard injury-Munich experiences. Toxicology 263(1):3-8. https://doi.org/10.1016/j. tox.2009.04.060

Kiistala U, Paavonen T, Saarelainen I, Aronen H, Asko-Seljavaara S, Kariniemi AL, Ingervo L, Niemitalo S (1989) Epidermis is the origin of high creatine kinase levels in skin blister fluid. Acta Dermato-venereol 69(4):284-287

Kilic E, Ortatatli M, Sezigen S, Eyison RK, Kenar L (2018) Acute intensive care unit management of mustard gas victims: the Turkish experience. Cutan Ocular Toxicol 37(4):332-337. https ://doi.org/10.1080/15569527.2018.1464018

Krämer DM, Pathak MA, Güngerich U (1971) Isolation and characterization of epidermal DNA and RNA from guinea pig skin. J Invest Dermatol 56(1):55-60. https://doi.org/10.1111/15231747.ep12291904

Lenz H, Schmidt M, Welge V, Schlattner U, Wallimann T, Elsässer H-P, Wittern K-P, Wenck H, Stäb F, Blatt T (2005) The creatine kinase system in human skin: protective effects of creatine against oxidative and UV damage in vitro and in vivo. J Invest Dermatol 124(2):443-452. https://doi.org/10.1111/j.0022202X.2004.23522.x
Lüling R, Schmeißer W, Siegert M, Mückter H, Dietrich A, Thiermann H, Gudermann T, John H, Steinritz D (2020) Identification of creatine kinase and alpha- 1 antitrypsin as protein targets of alkylation by sulfur mustard. Drug Test Anal. https://doi. org/10.1002/dta.2916

Moser J, Levine CF, Thomas-Dunmeyer DR, Smith WJ (2004) Cross-linking interferes with assessing sulfur mustard-induced DNA damage in human peripheral blood lymphocytes using the comet assay. Toxicol Mech Methods 14(3):195-202. https://doi. org/10.1080/15376520490429120

Noort D, Verheij ER, Hulst AG, de Jong LP, Benschop HP (1996) Characterization of sulfur mustard induced structural modifications in human hemoglobin by liquid chromatography-tandem mass spectrometry. Chem Res Toxicol 9(4):781-787. https://doi. org/10.1021/tx9502148

Noort D, Hulst AG, de Jong LP, Benschop HP (1999) Alkylation of human serum albumin by sulfur mustard in vitro and in vivo: mass spectrometric analysis of a cysteine adduct as a sensitive biomarker of exposure. Chem Res Toxicol 12(8):715-721. https ://doi.org/10.1021/tx9900369

Noort D, Fidder A, Degenhardt-Langelaan CEAM, Hulst AG (2008) Retrospective detection of sulfur mustard exposure by mass spectrometric analysis of adducts to albumin and hemoglobin: an in vivo study. J Anal Toxicol 32(1):25-30. https://doi.org/10.1093/ $\mathrm{jat} / 32.1 .25$

Organisation for the Prohibition of Chemical Weapons (2015) Report of the OPCW fact-finding mission in Syria regarding alleged incidents in Marea, Syrian Arab Republic August 2015: Note by the Technical Secretariat. https://www.opcw.org/sites/default/files/ documents/2018/11/s-1320-2015_e_.pdf. Accessed 01 Nov 2020

Paavonen T, Aronen H, Saarelainen I, Neittaanmäki H, Hjelm I, Kiistala U (1988) The BB-isoenzyme is a major component of creatine kinase in skin blister fluid. Br J Dermatol 118(6):753757. https://doi.org/10.1111/j.1365-2133.1988.tb02592.x

Papadopoulos JS, Agarwala R (2007) COBALT: constraint-based alignment tool for multiple protein sequences. Bioinform (Oxf Engl) 23(9):1073-1079. https://doi.org/10.1093/bioinformatics/ btm076

Perryman M, Strauss AW, Buettner TL, Roberts R (1983) Molecular heterogeneity of creatine kinase isoenzymes. Biochimica et Biophysica Acta (BBA) Protein Struct Mol Enzymol 747(3):284-290. https://doi.org/10.1016/0167-4838(83)90107-3

Quillen C (2016) The islamic state's evolving chemical arsenal. Stud Conflict Terror 39(11):1019-1030. https://doi.org/10.1080/10576 10X.2016.1154364

Renshaw BP (1946) Mechanisms in production of cutaneous injuries by sulfur and nitrogen mustards: report of division 9. In: National Defense Research Committee (ed) Chemical Warfare Agents and related Chemical Problems, vol 1, Washington DC, pp 479-518

Riviere JE, Brooks JD, Williams PL, Monteiro-Riviere NA (1995) Toxicokinetics of topical sulfur mustard penetration, disposition, and vascular toxicity in isolated perfused porcine skin. Toxicol Appl Pharmacol 135(1):25-34. https://doi.org/10.1006/taap.1995.1205

Rosenthal DS, Simbulan-Rosenthal CM, Iyer S, Spoonde A, Smith W, Ray R, Smulson ME (1998) Sulfur mustard induces markers of terminal differentiation and apoptosis in keratinocytes via a Ca2+calmodulin and caspase-dependent pathway. J Invest Dermatol 111(1):64-71. https://doi.org/10.1046/j.1523-1747.1998.00250.x

Schlattner U, Möckli N, Speer O, Werner S, Wallimann T (2002) Creatine kinase and creatine transporter in normal, wounded, and diseased skin. J Invest Dermatol 118(3):416-423. https://doi. org/10.1046/j.0022-202x.2001.01697.x

Steinritz D, Striepling E, Rudolf K-D, Schröder-Kraft C, Püschel K, Hullard-Pulstinger A, Koller M, Thiermann H, Gandor F, Gawlik M, John H (2016) Medical documentation, bioanalytical evidence of an accidental human exposure to sulfur mustard and general 
therapy recommendations. Toxicol Lett 244:112-120. https://doi. org/10.1016/j.toxlet.2015.08.1105

www.opcw.org/chemical-weapons-convention Chemical Weapons Convention. Accessed 27 Jul 2020

Xu H, Nie Z, Zhang Y, Li C, Yue L, Yang W, Chen J, Dong Y, Liu Q, Lin Y, Wu B, Feng J, Li H, Guo L, Xie J (2014) Four sulfur mustard exposure cases: overall analysis of four types of biomarkers in clinical samples provides positive implication for early diagnosis and treatment monitoring. Toxicol Rep 1:533-543. https://doi. org/10.1016/j.toxrep.2014.07.017

Zhang Y, Yue L, Nie Z, Chen J, Guo L, Wu B, Feng J, Liu Q, Xie J (2014) Simultaneous determination of four sulfur mustard-DNA adducts in rabbit urine after dermal exposure by isotope-dilution liquid chromatography-tandem mass spectrometry. J Chromatogr B Anal Technol Biomed Life Sci 961:29-35. https://doi. org/10.1016/j.jchromb.2014.04.050
Zubel T, Bürkle A, Mangerich A (2018) Mass spectrometric analysis of sulfur mustard-induced biomolecular adducts: Are DNA adducts suitable biomarkers of exposure? Toxicol Lett 293:21-30. https ://doi.org/10.1016/j.toxlet.2017.12.014

Zubel T, Hochgesand S, John H, Steinritz D, Schmidt A, Bürkle A, Mangerich A (2019) A mass spectrometric platform for the quantitation of sulfur mustard-induced nucleic acid adducts as mechanistically relevant biomarkers of exposure. Arch Toxicol 93(1):61-79. https://doi.org/10.1007/s00204-018-2324-7

Publisher's Note Springer Nature remains neutral with regard to jurisdictional claims in published maps and institutional affiliations.

\section{Authors and Affiliations}

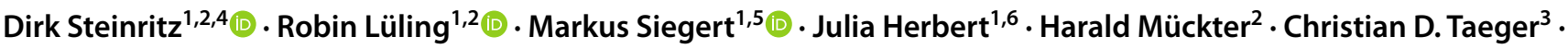 Thomas Gudermann ${ }^{2} \cdot$ Alexander Dietrich $^{2}$ (i) $\cdot$ Horst Thiermann ${ }^{1} \cdot$ Harald John ${ }^{1}$ (])}

Robin Lüling

rt11507@gmx.de

Markus Siegert

markus.siegert@student.hu-berlin.de

Julia Herbert

jh1588@pharmacy.rutgers.edu

Christian D. Taeger

Christian.Taeger@ukr.de

Thomas Gudermann

thomas.gudermann@1rz.uni-muenchen.de

Alexander Dietrich

alexander.dietrich@1rz.uni-muenchen.de

Horst Thiermann

horstthiermann@bundeswehr.org

Harald John

haraldjohn@bundeswehr.org
1 Bundeswehr Institute of Pharmacology and Toxicology, Neuherbergstraße 11, 80937 Munich, Germany

2 Walther-Straub-Institute of Pharmacology and Toxicology, Ludwig-Maximilians-Universität Munich (LMU), Goethestraße 33 / Nussbaumstraße 26, 80366 Munich, Germany

3 Department of Plastic-, Hand- and Reconstructive Surgery, University Hospital Regensburg, Franz-Josef-Strauß-Allee 11, 93053 Regensburg, Germany

4 Present Address: Bundeswehr Medical Service Academy, Ingolstädter Straße 240, 80939 Munich, Germany

5 Present Address: Proteros Biostrucures GmbH, Bunsenstraße 7a, 82152 Planegg, Germany

6 Present Address: Department of Pharmacology and Toxicology, Ernest Mario School of Pharmacy, Rutgers University, Piscataway, NJ, USA 